\title{
Faktor-faktor yang Berpengaruh pada Akurasi Kode diagnosis di Puskesmas Rawat Jalan Kota Malang
}

\section{Factors that Influence the Accuracy of Codefication in Outpatient Primary Health Cares in Malang}

\author{
Endang Sri DHS ${ }^{1}$, Mulyohadi Ali \\ ${ }^{1}$ Jurusan Kesehatan Terapan Politeknik Kesehatan Kementerian Kesehatan Malang \\ ${ }^{2}$ Laboratorium Farmakologi Fakultas Kedokteran Universitas Brawijaya Malang
}

\begin{abstract}
ABSTRAK
Akurasi kode diagnosis dalam rekam medik pasien kasus rawat jalan pada Puskesmas merupakan persyaratan penting sebagai sumber data epidemiologi karena besarnya kontribusi data Puskesmas sebagai layanan primer pada data nasional. Pengamatan dilapangan menunjukkan masih lemahnya akurasi kode diagnosis sesuai ICD-10 sehingaa penelitian inti dilakukan untuk mengeksplorasi keakuratan kode diagnosis penyakit berdasarkan ICD-10, serta menganalisa faktor-faktor mempengaruhi. Kajian cross sectional dilakukan di 5 Puskesmas Rawat Jalan Kota Malang, dengan faktor yang dikaji meliputi pengalaman kerja, pelatihan tentang kodefikasi diagnosis penyakit, ketersediaan buku ICD-10, ketersediaan SOP kode diagnosis dan pengetahuan tentang kodefikasi diagnosis penyakit, dan variabel terikatnya adalah akurasi kodefikasi diagnosis penyakit. Jumlah responden 15 koder terdiri dari 5 tenaga dokter, 5 tenaga dokter gigi dan 5 tenaga perawat yang berasal dari 5 Puskesmas dan kesemuanya terlibat dalam pengkodean diagnosis penyakit di Puskesmas. Jumlah sampel dokumen RM rawat jalan yang diperiksa keakuratannya dari setiap Puskesmas sebanyak 36 dokumen, yang diambil dengan metode purposive sampling. Hasil analisa keakuratan kode diagnosis menunjukkan $>50 \%$ responden menunjukkan akurasi kodefikasi diagnosis yang rendah $(<50 \%)$. Hasil uji Fisher's Exact Test secara menunjukkan hubungan signifikan pengalaman kerja mengkode, tersedianya standar operasional prosedur (SOP) kode diagnosis dan pengetahuan tentang kodefikasi diagnosis penyakit, terhadap akurasi kode. Pengetahuan koder tentang kodefikasi diagnosis penyakit merupakan faktor yang paling berperan terhadap keakuratan kodefikasi diagnosis penyakit.
\end{abstract}

Kata Kunci: Akurasi data, determinan, ICD X, pelayanan primer, rekam medik

\begin{abstract}
Accuracy on diagnosis codes in medical records of outpatient patients at the Primary Health Centers is an important requirement as an epidemiological data source due to the large contribution of Primary Health Center data as primary services to national data. Field observations showed that the diagnosis code accuracy according to the ICD-10 is still weak, so this research aimed to explore the accuracy of disease diagnosis coding based on ICD-10, as well as to analyze the influencing factors. This cross-sectional study was conducted in five Outpatient Primary Health Cares (PHCs) in Malang upon the factors including working experience, training on the coding of disease diagnosis, availability of ICD-10 books, availability of codefication SOP, and knowledge of coding; while the dependent variable was the accuracy of coding. The number of respondents was 15 coders consisting of 5 physicians, five dentists, and five nurses that were chosen from 5 Outpatient PHCs, and all were involved in disease diagnosis coding. The number of outpatient medical records from each PHC for accuracy examination was 36 documents that were taken using purposive sampling method. The results of coding accuracy analysis showed more than 50\% of the respondents had a low accuracy of diagnosis coding (below 50\%). The Fisher's Exact Test results show a significant relationship between working experience on coding, availability of codefication SOP and knowledge about disease diagnosis coding to the coding accuracy. Coder's knowledge about coding the disease diagnosis is the factor that plays a role in the accuracy of the coding of disease diagnosis.
\end{abstract}

Keywords: Coding accuracy, factors influencing the accuracy of diagnosis coding

Korespondensi: Endang Sri DHS. Jurusan Kesehatan Terapan Politeknik Kesehatan Kementerian Kesehatan Malang, Jl. Besar ljen $77 \mathrm{C}$ Malang Jawa Timur 65112 Tel. (341) 566075 Email: wiwik.esd@gmail.com

DOI: http://dx.doi.org/10.21776/ub.jkb.2019.030.03.12 


\section{PENDAHULUAN}

Pelaksanaan pengkodean diagnosis penyakit di Puskesmas merupakan kegiatan yang sangat penting yaitu dengan mengklasifikasikan diagnosis penyakit menjadi beberapa kelompok untuk kepentingan laporan penyakit yang dilakukan Puskesmas setiap bulannya, serta berperan penting dalam sistem pembiayaan pada Puskesmas itu sendiri. Berdasarkan Kepmenkes RI Nomor 50/MENKES/SK/I/1998 tentang pemberlakuan Klasifikasi Statistik Internasional mengenai penyakit revisi kesepuluh, dan Kepmenkes RI Nomor 844/MENKES /SK/X/2006 tentang penetapan standar kode data bidang kesehatan, ditetapkan bahwa International Statistical Classification of Diseases and Related Health Problems Tenth Revision (ICD-10) merupakan acuan yang digunakan secara nasional di Indonesia untuk mengkode diagnosis penyakit. Pengkodean harus sesuai ICD-10 guna mendapatkan kode yang akurat karena hasilnya digunakan untuk mengindeks pencatatan penyakit, pelaporan nasional dan internasional morbiditas dan mortalitas, analisis pembiayaan pelayanan kesehatan, serta untuk penelitian epidemiologi dan klinis (1). Diagnosis penyakit pasien apabila tidak terkode dengan akurat maka informasi yang dihasilkan akan mempunyai tingkat validasi data yang rendah. Hal ini tentu akan mengakibatkan ketidak akuratan dalam pembuatan laporan, misalnya laporan morbiditas rawat jalan, laporan sepuluh besar penyakit ataupun klaim BPJS (2).

Faktor-faktor yang mempengaruhi akurasi kode diantaranya adalah tenaga medis, dan tenaga rekam medis. Penetapan diagnosis seorang pasien merupakan kewajiban, hak, dan tanggungjawab dokter (tenaga medis) terkait. Dokter sebagai penentu perawatan harus memilih kondisi utama (yaitu penyakit utama yang diderita pasien setelah dilakukan pemeriksaan yang lebih mendalam) dan kondisi lain (yaitu kondisi yang terdapat bersamaan atau berkembang selama episode asuhan kesehatan, dan mempengaruhi asuhan pasien), dalam periode perawatan. Tenaga rekam medis sebagai pemberi kode bertanggung jawab atas keakuratan kode dari suatu diagnosis yang telah ditetapkan oleh tenaga medis. Sebelum memberikan kode penyakit, tenaga rekam medis harus mengkaji data rekam medis pasien untuk menemukan hal yang kurang jelas atau tidak lengkap (3).

Berdasarkan wawancara yang dilakukan pada saat studi pendahuluan yang dilakukan pada bulan Januari 2016 terhadap dokter dan perawat yang terlibat dalam pengkodean di Puskesmas Janti Kota Malang, diperoleh informasi bahwa Puskesmas belum mempunyai tenaga profesi rekam medis yang khusus bertanggung jawab terhadap pengkodean diagnosis penyakit di Puskesmas, sehingga kegiatan pengkodean penyakit dilakukan oleh tenaga dokter, dokter gigi, bidan atau perawat, yang tidak berlatarbelakang pendidikan rekam medis ataupun belum pernah mendapatkan pelatihan tentang kode diagnosis penyakit. Pengkodean diagnosis penyakit di Puskesmas selama ini masih dilakukan atas dasar kemampuan otodidak, atau menggunakan daftar kode yang dibuat sendiri oleh Puskesmas, sehingga kode diagnosis yang dilakukan jauh dari keakuratan. Tenaga kontrak perekam medis yang baru direkrut masih belum difungsikan sebagai tenaga pengkode, melainkan sebagai tenaga di loket pendaftaran, atau sebagai penata dokumen rekam medis.

Beberapa penelitian menunjukkan bahwa keakuratan pengkodean diagnosis penyakit di Puskesmas masih rendah. Penelitian Pramono dkk. di Puskesmas Gondokusuman II Kota Yogyakarta pada tahun 2012 menunjukkan bahwa dari 385 berkas rekam medis yang dikode, sebanyak 211 dokumen $(54,8 \%)$ yang tidak akurat (4). Hal ini menunjukkan bahwa keakuratan pengkodean penyakit di Puskesmas masih rendah. Akurasi pengkodean diagnosis penyakit berdasarkan standar pelayanan minimal bidang rekam medis yang diatur dalam Permenkes No. 129 tahun 2008, harus mencapai 100\%. Penelitian tersebut menyebutkan bahwa beberapa penyebab dari ketidakakuratan pengkodean antara lain tidak sesuainya kualifikasi SDM yang bertugas untuk mengkode diagnosis serta tidak optimalnya penggunaan buku ICD-10 sebagai panduan untuk mengkode diagnosis penyakit. Penelitian lain yang dilakukan oleh Lestari di Puskesmas Mijen Kota Semarang pada bulan Juni 2014 menunjukkan tingkat pengetahuan petugas kesehatan di Puskesmas tentang pengkodean penyakit yang masih rendah. Hasil pengukuran menunjukkan $80 \%$ responden tidak mengetahui kamus kedokteran, ICD 9 dan ICD 10 untuk sarana yang digunakan untuk pengkodean, dan $100 \%$ responden tidak pernah mengikuti pelatihan kode diagnosis (5). Tujuan penelitian ini adalah untuk mengetahui faktor-faktor yang berpengaruh terhadap keakuratan kode diagnosis penyakit di Puskesmas Rawat Jalan Kota Malang.

\section{METODE}

Penelitian dilakukan dengan pendekatan cross sectional, yang mengukur keakuratan kode diagnosis penyakit terhadap seluruh dokumen rekam medis rawat jalan serta faktor-faktor yang berhubungan dengan akurasi tersebut. Jumlah Puskesmas sebanyak 5 Puskesmas rawat jalan dipilih dari 10 Puskesmas rawat jalan yang ada di Kota Malang yaitu Puskesmas Arjuno, Rampal Celaket, Cisadea, Janti dan Ciptomulyo, yang dipilih secara acak (simple random sampling) dengan melalui lotere. Petugas koder berasal dari 5 Puskesmas. Berdasarkan pengukuran untuk variabel terikat ditetapkan sebagai populasinya adalah seluruh dokumen Rekam Medis Rawat Jalan dari pasien yang dikode pada saat pengumpulan data dilakukan.

Pengukuran variabel bebas populasinya adalah petugas koder di Puskesmas, yaitu dokter, dokter gigi dan perawat khususnya yang bertugas memasukkan data pasien ke dalam format laporan. Masing-masing Puskesmas dipilih 3 petugas koder yang terdiri dari 1 tenaga dokter, 1 tenaga dokter gigi dan 1 tenaga perawat yang terlibat dalam pengkodean diagnosis penyakit setiap harinya, sehingga jumlah keseluruhan responden koder sebanyak 15 orang. Pengambilan sampel dokumen rekam medis (DRM) menggunakan metode purposive sampling (dengan memilah dokumen yang dikode oleh dokter, dokter gigi atau oleh perawat). Dengan jumlah populasi 500 DRM perhari (dengan rata-rata jumlah pasien 100 per-hari dari tiap-tiap Puskesmas), ditentukan jumlah sampel menggunakan tabel Isaac dan Michael dengan taraf kesalahan $10 \%$ diperoleh total sampel sebanyak 180 DRM (6). Jumlah sampel masing-masing Puskesmas diperoleh sebanyak 36 DRM (12 DRM dikode oleh dokter, 12 DRM dikode oleh dokter gigi dan 12 DRM dikode oleh perawat). Kriteria inklusi sampel adalah berkas rekam medis rawat jalan yang dikode oleh dokter, dokter gigi dan perawat, pada waktu pengumpulan data dilakukan.

Variabel terikat adalah keakuratan kode diagnosis penyakit. Sebagai variabel bebas adalah pengalaman kerja, 
pelatihan kodefikasi diagnosis penyakit yang pernah diikuti, tersedianya buku ICD-10 di Puskesmas, tersedianya SOP kodefikasi diagnosis penyakit dan pengetahuan tentang kodefikasi diagnosis penyakit). Instrumen yang digunakan berupa form checklist untuk pencatatan keakuratan kode diagnosis dengan menggunakan pedoman buku ICD-10 volume 1, 2, dan 3; serta kuesioner yang berisi 20 pertanyaan dengan 12 diantaranya merupakan pertanyaan untuk mengukur pengetahuan tenaga koder tentang kode diagnosis.

Pengumpulan data dilakukan dengan menggunakan kuesioner yang diberikan kepada tenaga koder di Puskesmas yaitu dokter, dokter gigi dan perawat. Kuesioner berisi 20 pertanyaan, yang terdiri dari 8 pertanyaan untuk memperoleh data khusus responden seperti: usia, jenis kelamin, pendidikan terakhir, pengalaman kerja dalam mengkode diagnosis penyakit pasien, frekuensi pelatihan tentang kodefikasi diagnosis penyakit diagnosis penyakit, ketersediaan buku ICD-10 volume 1, 2 dan 3 di Puskesmas serta ketersediaan SOP kodefikasi diagnosis penyakit di Puskesmas. Sebanyak 12 pertanyaan lainnya adalah untuk menggali pengetahuan responden tentang pengkodean diagnosis penyakit. Dua belas pertanyaan ini berisi tentang teori cara penggunaan buku ICD-10 dan menentukan kode diagnosis penyakit. Pengalaman kerja dihitung sejak responden mulai terlibat dalam pengkodean diagnosis penyakit di Puskesmas, dengan mengelompokkan pengalaman kerja mengkode kurang dari 3 tahun dan lebih dari 3 tahun. Pengelompokan ini dikarenakan petugas koder bukan berlatar belakang pendidikan perekam medis sehingga dengan pengalaman kerja kodefikasi diagnosis penyakit lebih dari 3 tahun diharapkan kemampuan kodefikasi diagnosis penyakitnya mendekati kompetensi seorang perekam medis.

Untuk pelatihan kodefikasi diagnosis penyakit apakah responden sudah pernah mendapatkan pelatihan tentang kode diagnosis sejak responden terlibat dalam pengkodean di Puskesmas. Berdasarkan skor hasil pengukuran pengetahuan responden tentang pengkodean diagnosis penyakit, responden dikelompokkan menjadi dua yaitu yang mendapat skor 60 keatas dan yang dibawah 60 . Batas skor 60 dianggap sebagai batas lulus untuk pengukuran pengetahuan petugas koder. Kuesioner yang digunakan untuk mengetahui pengetahuan responden tidak melalui uji validitas dan reliabilitas instrumen karena mengutip dari soal-soal yang diujikan kepada mahasiswa Program Studi D III Perekam Medis di Poltekkes Kemenkes Malang.

Tahap berikutnya dilakukan pemeriksaan keakuratan kode diagnosis penyakit terhadap seluruh dokumen rekam medis rawat jalan yang telah dijadikan sebagai sampel terpilih pada setiap Puskesmas dan kemudian dilakukan penghitungan persentase keakuratan kode diagnosis penyakit. Pemeriksaan keakuratan kode diagnosis dilakukan sendiri oleh peneliti yang sehari-hari adalah sebagai dosen mata kuliah Klasifikasi dan Kode diagnosis Penyakit di Kampus Poltekkes Kemenkes Malang, sedangkan responden yang mengkode adalah responden yang sama dengan yang mengisi kuesioner. Untuk diagnosis yang dikode oleh responden adalah diagnosis penyakit pasien yang datang berobat saat pengumpulan data dilakukan, jadi merupakan diagnosis yang terakhir yang tercantum di DRM pasien. Pengukuran akurasi kode untuk tiap-tiap responden dengan jumlah dokumen yang dikode masing-masing 12 DRM, dihitung prosentase akurasi kodenya kemudian dikelompokkan menjadi dua yaitu kelompok responden dengan prosentase akurasi kodefikasi diagnosis penyakit $\geq 50 \%$ dan kelompok responden dengan prosentase akurasi kodefikasi diagnosis penyakit $<50 \%$.

Analisa univariat data secara diskriptif disajikan dalam bentuk tabel frekuensi. Untuk mengetahui hubungan faktor pengalaman kerja memberikan kode penyakit, pelatihan tentang kode diagnosis, ketersediaan buku ICD10 , SOP kodefikasi diagnosis penyakit serta pengetahuan tentang kode diagnosis terhadap keakuratan pengkodean diagnosis penyakit di 5 Puskesmas Rawat Jalan Kota Malang secara parsial terhadap keakuratan pengkodean diagnosis penyakit, maka dilakukan analisa bivariat, dengan menggunakan uji Fisher's Exact Test dengan tingkat kemaknaan $\alpha=0,05$. Apabila nilai $p$ lebih kecil dari $\alpha=0,05$, maka ada hubungan antara dua variabel tersebut. Untuk mengetahui hubungan simultan dari seluruh variabel bebas terhadap variabel terikat dilakukan analisa regresi logistik berganda dengan tingkat kepercayaan 95\%. Analisis data menggunakan program SPSS versi 21.

\section{HASIL}

Pada analisa univariat disajikan distribusi frekuensi data responden yang diperoleh dari kuesioner dan observasi akurasi kodefikasi diagnosis penyakit. Tabel 1 menunjukkan sebagian besar $(53,3 \%)$ kemampuan petugas dalam melakukan kode diagnosis masih belum akurat dengan prosentase akurasi kode dibawah $50 \%$. Pengalaman kerja responden dalam bidang pengkodean terbanyak mempunyai pengalaman lebih dari 3 tahun $(53,3 \%)$, sebagian besar belum pernah ikut pelatihan kodefikasi diagnosis penyakit $(66,7 \%)$, sebagian besar di Puskesmas responden sudah tersedia buku ICD-10 lengkap (60\%) namun dalam proses pengkodean sebagian besar Puskesmas (60\%) belum memiliki Standar Operasional Prosedur (SOP). Dari segi pengetahuan tentang kode diagnosis, lebih dari separuh responden $(53,3 \%)$ memiliki skor pengetahuan dibawah 60 .

Tabel 1. Gambaran akurasi kode diagnosis dan faktor yang behubungan dengan akurasi

\begin{tabular}{|c|c|c|c|}
\hline No & Variabel & Frek. & $\%$ \\
\hline \multirow[t]{3}{*}{1.} & $\begin{array}{l}\text { Akurasi Kodefikasi diagnosis } \\
\text { penyakit: }\end{array}$ & & \\
\hline & - $\%$ akurasi $<50 \%$ & 8 & 53,3 \\
\hline & - $\quad \%$ akurasi $\geq 50 \%$ & 7 & 46,7 \\
\hline \multirow[t]{3}{*}{2.} & $\begin{array}{l}\text { Pengalaman Kerja Kodefikasi } \\
\text { diagnosis penyakit: }\end{array}$ & & \\
\hline & $-\quad \leq 3$ Tahun & 7 & 46,7 \\
\hline & - $>3$ Tahun & 8 & 53,3 \\
\hline \multirow[t]{3}{*}{3.} & $\begin{array}{l}\text { Pelatihan Kodefikasi } \\
\text { diagnosis penyakit: }\end{array}$ & & \\
\hline & - Tidak Pernah & 10 & 66,7 \\
\hline & - Pernah & 5 & 33,3 \\
\hline \multirow[t]{3}{*}{4.} & Ketersediaan Buku ICD-10: & & \\
\hline & - Tidak Ada/Tidak Lengkap & 6 & 40 \\
\hline & - Ada & 9 & 60 \\
\hline \multirow[t]{3}{*}{5.} & $\begin{array}{l}\text { Ketersediaan SOP Kodefikasi } \\
\text { diagnosis penyakit: }\end{array}$ & & \\
\hline & - Tidak Ada & 9 & 60 \\
\hline & - Ada & 6 & 40 \\
\hline
\end{tabular}


Tabel 1. Gambaran akurasi kode diagnosis dan faktor yang behubungan dengan akurasi (Lanjutan)

\begin{tabular}{llll}
\hline No & \multicolumn{1}{c}{ Variabel } & Frek. & $\%$ \\
\hline 6. & Pengetahuan Tentang & & \\
& Kodefikasi diagnosis \\
& penyakit: & & \\
& - Skor $<60$ & 8 & 53,3 \\
& - Skor $\geq 60$ & 7 & 46,7 \\
\hline
\end{tabular}

Hasil analisis bivariat masing-masing variabel bebas terhadap variabel terikat dengan menggunakan uji Fisher's Exact Test, menunjukkan bahwa untuk faktor pengalaman kerja dalam bidang kodefikasi diagnosis penyakit didapatkan nilai OR=18 (95\% Cl: 1,27-255,74; $\mathrm{p}=0,041)$. Berarti hal ini menunjukkan, koder dengan pengalaman kerja lebih dari 3 tahun terbukti 18 kali lebih besar berpeluang menunjukkan akurasi kodefikasi $>50 \%$. Untuk faktor ketersediaan SOP kodefikasi diagnosis penyakit didapatkan nilai OR=17,5 (95\% Cl: 1,22-250,36; $p=0,041)$, yang berarti ketersediaan SOP kodefikasi diagnosis penyakit terbukti 17,5 kali lebih besar berpeluang menunjukkan akurasi kodefikasi $>50 \%$. Demikian pula untuk faktor pengetahuan tentang kode diagnosis penyakit didapatkan nilai OR=42 (95\% Cl: $2,14-$ $825,72 ; p=0,010)$, yang berarti pengetahuan koder tentang kodefikasi diagnosis penyakit dengan skor $\geq 60$ terbukti 42 kali lebih besar berpeluang menunjukkan akurasi kodefikasi $>50 \%$. Faktor pelatihan tentang kodefikasi diagnosis penyakit dan faktor ketersediaan buku ICD-10 secara lengkap, kedua-duanya secara statistik tidak berhubungan dengan akurasi kode diagnosis penyakit $(p=0,119)$.

Analisa regresi ganda dilakukan dengan menggunakan uji statistik non parametrik yaitu analisis regresi logistik ganda (Tabel 3). Hasil menunjukkan bahwa pengalaman kerja, pelatihan kodefikasi diagnosis penyakit, ketersediaan buku ICD-10, tersedianya SOP kodefikasi diagnosis penyakit dan skor pengetahuan tentang kode diagnosis secara bersamasama tidak berhubungan dengan akurasi kodefikasi diagnosis penyakit $(p>0,05)$.

\section{DISKUSI}

\section{Analisa Keakuratan Kode Diagnosis}

Hasil studi menunjukkan bawa akurasi kode diagnosis oleh semua koder masih rendah $(<50 \%)$. Selama ini tenaga koder di Puskesmas hanya mengandalkan lembaran kode yang diberikan oleh BPJS karena berkaitan dengan klaim yang diajukan ke BPJS, selain itu mereka juga menggunakan cara lain untuk pencarian kode diagnosis yaitu lewat internet karena lebih mudah dan cepat. Kedua cara tersebut tidak sepenuhnya mengacu pada tata cara klasifikasi kode diagnosis berdasarkan ICD-10. WHO (2014) dan Pemerintah Indonesia melalui Kepmenkes RI No 50 tahun 1998 dan No 844 tahun 2006, telah menetapkan Buku ICD-10 volume 1, 2, dan 3, sebagai standar acuan klasifikasi dan kode diagnosis penyakit di Rumah Sakit dan Puskesmas. Kode yang akurat mutlak harus diperoleh agar laporan yang dibuat dapat dipertanggungjawabkan termasuk laporan morbiditas dan mortalitas khususnya di tingkat Kabupaten/Kota. Kemampuan kodefikasi koder Puskesmas yang sebagian besar (53,3\%) tingkat

Tabel 2. Faktor yang berhubungan dengan akurasi kode diagnosis

\begin{tabular}{|c|c|c|c|c|c|c|c|}
\hline \multirow{2}{*}{ No. } & \multirow{2}{*}{ Faktor yang behubungan } & \multicolumn{2}{|c|}{ \% Akurasi Kodefikasi } & \multirow{2}{*}{ Sig. } & \multirow{2}{*}{ Odds Ratio (OR) } & \multicolumn{2}{|c|}{ 95\% Confidence Interval } \\
\hline & & $<50$ & $\geq 50$ & & & Lower & Upper \\
\hline \multirow[t]{3}{*}{1.} & $\begin{array}{l}\text { Pengalaman Kerja Kodefikasi } \\
\text { diagnosis penyakit }\end{array}$ & & & 0,041 & 18,000 & 1,267 & 255,744 \\
\hline & $\square \leq 3$ tahun & 6 & 1 & & & & \\
\hline & $\square>3$ tahun & 2 & 6 & & & & \\
\hline \multirow[t]{3}{*}{2.} & $\begin{array}{l}\text { Pelatihan Kodefikasi diagnosis } \\
\text { penyakit }\end{array}$ & & & 0,119 & 9,333 & 0,711 & 122,570 \\
\hline & $\square$ Tidak Pernah & 7 & 3 & & & & \\
\hline & $\square$ Pernah & 1 & 4 & & & & \\
\hline \multirow[t]{3}{*}{3.} & Ketersediaan Buku ICD 10 & & & & & & \\
\hline & $\square$ Tidak Ada & 5 & 1 & 0,119 & 10,000 & 0,777 & 128,775 \\
\hline & $\square$ Ada Lengkap & 3 & 6 & & & & \\
\hline \multirow[t]{3}{*}{4.} & Ketersediaan SOP & & & & & & \\
\hline & $\square$ Tidak Ada & 7 & 2 & 0,041 & 17,500 & 1,223 & 250,357 \\
\hline & $\square$ Ada & 1 & 5 & & & & \\
\hline \multirow[t]{3}{*}{5.} & Skor Pengetahuan & & & & & & \\
\hline & $\square<60$ & 7 & 1 & 0,010 & 42,000 & 2,136 & 825,715 \\
\hline & $\square \geq 60$ & 1 & 6 & & & & \\
\hline
\end{tabular}

Tabel 3. Hasil analisa multivariat dengan uji regresi logistik ganda

\begin{tabular}{lrrrrrr}
\hline \multicolumn{1}{c}{ Variabel } & \multicolumn{1}{c}{ B } & \multicolumn{1}{c}{ S.E. } & Wald & df & \multicolumn{1}{c}{ Sig } \\
\hline Pengalaman kerja & 37,274 & 13255,532 &, 000 & 1 &, 998 & 15420327346958310,000 \\
Pelatihan & 37,821 & 16780,150 &, 000 & 1 &, 998 & 26642549195131968,000 \\
Ketersediaan buku & $-112,046$ & 27448,441 &, 000 & 1 &, 997 &, 000 \\
SOP & $-74,128$ & 19075,908 &, 000 & 1 &, 997 &, 997 \\
Pengetahuan & $-75,343$ & 19628,902 &, 000 & 1 &, 000 \\
Konstan & 92,699 & 22208,908 &, 000 & 1 &, 997 &, 000 \\
\hline
\end{tabular}


keakuratannya masih dibawah 50\%, hal ini akan berdampak pada tingkat validitas data laporan ke Dinas Kesehatan. Data laporan yang tidak valid akan menyebabkan pengambilan keputusan yang kurang tepat, baik di tingkat manajer Puskesmas, Dinas Kesehatan Kabupaten/Kota, Propinsi maupun di tingkat Pusat, khususnya dalam penyusunan program kerja di bidang pelayanan kesehatan. Akurasi data merupakan faktor kunci dalam proses pengambilan kebijakan berbasis bukti sebagai wujud pemerintahan yang baik.

Faktor-faktor yang Berpengaruh terhadap Keakuratan Kode Diagnosis Penyakit

Meskipun tidak ada hubungan simultan antara semua faktor yang dikaji, namun secara parsial faktor pengalaman kerja dalam bidang kodefikasi diagnosis penyakit selama lebih dari tiga tahun, ketersediaan SOP kodefikasi diagnosis penyakit serta pengetahuan petugas dalam kodefikasi diagnosis penyakit berhubungan dengan akurasi kode diagnosis. Studi sebelumnya juga menunjukkan bahwa faktor-faktor yang memungkinkan menjadi penyebab terjadinya ketidaktepatan pemberian kode diagnosis adalah ketidakpahaman petugas dalam mengkode, kurangnya pengalaman kerja petugas dalam bidang kodefikasi diagnosis penyakit, SOP tentang pengkodean tidak terlaksana dengan benar menyebabkan pengkodean tidak dilakukan dengan tepat, kurangnya pelatihan khusus kepada petugas koder tentang cara tepat pengkodean, serta kurang lengkapnya sarana kerja seperti ketersediaan buku ICD-10 vol 1, 2, dan $3(1,2)$.

Pengalaman kerja dalam bidang kodefikasi diagnosis penyakit berhubungan dengan keakuratan kodefikasi diagnosis penyakit, dengan nilai signifikansi 0,041 $(p<0,05)$ dan nilai OR=18 (95\% Cl: 1,27-255,74). Hal ini berarti bahwa pengalaman kerja tenaga dokter, dokter gigi maupun perawat yang bertugas sebagai petugas koder di Puskesmas selama lebih dari tiga tahun berdampak cukup kuat pada kemampuan petugas tersebut dalam mengkode diagnosis penyakit pasien di Puskesmas dengan lebih akurat. Hasil ini sesuai dengan hasil penelitian Maryati dkk dan Yuniati yang menunjukkan bahwa pengalaman kerja mengkode diagnosis penyakit lebih dari lima tahun berpengaruh terhadap kualitas kode diagnosis $(7,8)$. Semakin lama petugas bekerja dalam bidang kodefikasi diagnosis penyakit semakin terampil dan kompeten petugas tersebut dalam mengkode dan hasil kode diagnosisnya akan semakin akurat $(7,8)$. Penelitian yang dilakukan oleh Farzandipour et al., menunjukkan hasil yang berbeda, koders dengan pengalaman kerja $\leq 5$ tahun menunjukkan akurasi kodefikasi diagnosis penyakit lebih baik dari koder dengan pengalaman kerja $>5$ tahun, dengan $\mathrm{OR}=3,54$; $\mathrm{Cl}=2,08-6,01 ; \mathrm{p}<0,0001$. Hal ini disebabkan koder dengan pengalaman kerja $>5$ tahun cenderung menggunakan hafalan (daya ingat) dalam mengkode sehingga memungkinkan terjadinya kekeliruan dalam menentukan kode, sedangkan bagi tenaga koder yang masih sedikit pengalamannya lebih menggunakan pedoman ICD-10 dalam mengkode (9).

Hubungan kuat ditemukan antara ketersediaan SOP kodefikasi diagnosis penyakit dengan keakuratan kode diagnosis penyakit. Hatta dalam bukunya menjelaskan sembilan (4) langkah dasar dalam menentukan kode diagnosis yang menjadi pedoman (SOP) bagi koder didalam melakukan proses kodefikasi diagnosis penyakit.
Pedoman kodefikasi diagnosis penyakit merupakan suatu tahapan instruksi atau perintah kerja tentang langkahlangkah dalam memberi kode pada diagnosis pasien yang tertulis dan harus diikuti demi mencapai keseragaman dalam mengkode diagnosis pasien. Selain itu dengan adanya SOP kodefikasi diagnosis penyakit, akan mengurangi terjadinya kesalahan dalam kegiatan kodefikasi diagnosis pasien karena segala instruksi dan perintah kerja sudah tersusun dan tertulis dengan jelas sehingga dapat mempengaruhi akurasi kodefikasi diagnosis penyakit. Penelitian Saputro dkk, dan Suriawan dkk, membuktikan tidak ada SOP pengkodean mempengaruhi akurasi dari kode diagnosa penyakit $(2,3)$. Hal tersebut berbeda dengan hasil penelitian yang dilakukan oleh Maiga, dkk. yang menunjukkan bahwa semua responden (koder) mengetahui adanya SOP pengkodean akan tetapi SOP tersebut tidak dipahami sehingga tidak berdampak pada keakuratan dalam mengkode diagnosis penyakit (10).

Keakuratan kodefikasi diagnosis penyakit di 5 Puskesmas rawat jalan Kota Malang juga dipengaruhi oleh pengetahuan petugas tentang kodefikasi diagnosis penyakit sebagai faktor yang memunyai hubungan terkuat. Hasil penelitian ini sejalan dengan penelitian Utami, Sudra dkk, dan Widjaya dkk. yang membuktikan bahwa pengetahuan petugas tentang kodefikasi diagnosis penyakit yang baik dapat meningkatkan keakuratan kode diagnosis penyakit $(1,6)$. Pedoman Depkes RI dan update WHO juga menyebutkan penyebab ketidakakuratan kode diagnosis penyakit salah satunya adalah petugas koder yang bertanggung jawab dalam pemberian kode diagnosis pasien yang telah ditetapkan oleh dokter. Salah satu faktor yang menyebabkan koder salah dalam pemberian kode diagnosis penyakit adalah kurangnya pengetahuan koder tentang tata cara penggunaan ICD-10 dan ketentuanketentuan yang ada didalamnya serta pengetahuan penunjang lainnya yang berkaitan dengan kodefikasi diagnosis penyakit dan yang mendukung ketepatan dalam pemberian kode diagnosis. Hal ini membuktikan bahwa kurangnya pengetahuan koder (dokter, dokter gigi dan perawat) dalam penggunaan ICD-10 sebagai pedoman pengkodean akan menyebabkan kode diagnosis penyakit yang dilakukan menjadi tidak akurat.

Hasil uji bivariat untuk membuktikan adanya pengaruh pelatihan kodefikasi diagnosis penyakit terhadap akurasi kodefikasi diagnosis penyakit, menunjukkan tidak ada hubungan antara pelatihan kodefikasi diagnosis penyakit terhadap keakuratan kodefikasi diagnosis penyakit. Hasil ini sesuai dengan penelitian yang dilakukan oleh Widjaya $\mathrm{L}$ dkk, yang menunjukkan tidak ada hubungan antara pelatihan dengan keakuratan kodefikasi diagnosis penyakit. Penelitian tersebut menjelaskan bahwa pelatihan yang pernah diikuti oleh koder tidak dapat meningkatkan tingkat keakuratan kodefikasi diagnosis penyakitnya melainkan hanya sebatas menambah wawasan (11). Santos et al., dalam penelitiannya juga menunjukkan secara kuantitatif tidak ada hubungan antara pelatihan dengan peningkatan kualitas kodefikasi diagnosis penyakit, akan tetapi secara kualitatif dari hasil wawancara diperoleh hampir semua responden mengemukakan pendapat pentingnya pendidikan berkelanjutan atau pelatihan untuk meningkatkan kualitas seorang koder (12). Tujuan dari pelatihan adalah untuk menambah pengetahuan, ketrampilan dan perubahan sikap dari petugas yang dilatih. Beberapa faktor yang dapat 
menyebabkan tidak tercapainya tujuan pelatihan antara lain: materi pelatihan tidak sesuai dengan kompetensi (profesi) peserta latih, peserta latih tidak serius dalam mengikuti pelatihan karena bukan menjadi profesinya, belum pernah dilakukan evaluasi pasca pelatihan di tempat kerja serta tidak adanya kompensasi terhadap beban kerja yang bertambah sebagai dampak setelah mengikuti pelatihan (13). Petugas koder Puskesmas bukan dari profesi perekam medis melainkan sebagai tenaga medis dan paramedis yang tugas utamanya memberikan pelayanan pengobatan kepada pasien, sehingga pekerjaan mengkode diagnosis penyakit merupakan pekerjaan tambahan yang tidak diikuti dengan penambahan kompensasi penghasilan. Selain itu karena bukan menjadi kompetensinya menyebabkan ketidakseriusan petugas koder dalam memberikan kode diagnosis penyakit. Selama ini belum pernah dilakukan evaluasi terhadap petugas koder dalam mengkode diagnosis penyakit setelah mengikuti pelatihan, sehingga tidak diketahui manfaat pelatihan yang pernah diikuti petugas dalam meningkatkan ketrampilannya mengkode diagnosis penyakit di Puskesmas. Sebaliknya penelitian yang dilakukan oleh Rahayu H dkk, Windari, dan Maimun N dkk. tentang ketepatan kode penyakit, menunjukkan bahwa meskipun masing-masing koder berlatar belakang D3 Rekam Medis akan tetapi akurasi kodefikasi diagnosis penyakitnya hanya mencapai $69,59 \% ; 74,67 \%$ dan $79,9 \%$. $\mathrm{Hal}$ ini berarti koder masih membutuhkan pelatihan tentang kodefikasi diagnosis penyakit penyakit untuk lebih meningkatkan ketrampilan petugas dalam mengkode (1416). Joosse et al., dalam penelitiannya membuktikan bahwa pelatihan kodefikasi diagnosis penyakit untuk kasus trauma, terbukti dapat meningkatkan ketepatan dalam kodefikasi diagnosis penyakit (17). Demikian juga penelitian yang dilakukan oleh Maryati dkk, membuktikan bahwa koder yang mendapatkan pelatihan lebih banyak ( $\geq 5$ kali) menghasilkan kualitas kodefikasi diagnosis penyakit yang lebih baik (7). Pada penelitian ini 5 dari petugas koder yang sudah pernah mengikuti pelatihan kodefikasi diagnosis penyakit hanya pernah mengikuti pelatihan satu kali sehingga masih belum cukup untuk dapat meningkatkan pengetahuan dan ketrampilan petugas koder yang bukan berlatar belakang profesi perekam medis. Hal tersebut sesuai dengan pernyataan dari WHO, bahwa pendidikan pelatihan berlanjut selalu dibutuhkan bagi para koder untuk meningkatkan ketrampilannya sebagai pengkode yang handal.

Penelitian ini menunjukkan tidak ada hubungan ketersediaan buku ICD-10 terhadap keakuratan kode diagnosis penyakit. Empat dari lima Puskesmas menyatakan tersedia buku ICD-10, akan tetapi dokter, dokter gigi dan perawat lebih suka menggunakan lembaran daftar kode yang diberikan oleh BPJS atau

\section{DAFTAR PUSTAKA}

1. Utami YT. Hubungan Pengetahuan Coder dengan Keakuratan Kode Diagnosis Pasien Rawat Inap Jaminan Kesehatan Masyarakat Berdasarkan ICD-10 Di RSUD Simo, Boyolali. Jurnal Jurnal INFOKES Universitas Duta Bangsa Surakarta. 2015; 5(1): 13-25.

2. Saputro NT dan Nuryati. Faktor Penyebab Ketidaktepatan Kode Diagnosis di Puskesmas Mojolaban Sukoharjo Jawa Tengah. Jurnal menggunakan aplikasi android yang ada di telepon seluler ataupun dari internet, selain itu juga karena tenaga koder Puskesmas ini tidak memahami cara penggunaan buku ICD-10. Keadaan ini menunjukkan bahwa buku ICD-10 sebagai standar pedoman pengkodean tidak digunakan secara optimal. Hal ini sesuai dengan hasil penelitian dari Pramono dkk, yang menyebutkan bahwa buku ICD-10 tersedia di Puskesmas akan tetapi petugas koder tidak menggunakan buku ICD-10 tersebut sebagai pedoman pengkodean melainkan menggunakan hafalan kode yang ada di Sistim Informasi Manajemen Puskesmas (SIMPUS) (4). Kode diagnosis penyakit yang ada di SIMPUS adalah kode diagnosis penyakit yang dibuat sendiri oleh Puskesmas yang dimasukkan kedalam sistem pelaporan Puskesmas dan belum mengacu pada standar klasifikasi kodefikasi ICD-10. Oleh karena itu pihak pimpinan Puskesmas harus selalu melakukan monitoring evaluasi terhadap petugas koder di Puskesmas khususnya dalam penggunaan buku ICD-10 sebagai acuan petugas dalam melakukan kode diagnosis. Perlunya dilakukan kegiatan audit koding secara berkala dengan mengundang ahli koding atau yang dianggap kompeten dalam kodefikasi diagnosis penyakit untuk mengevaluasi hasil kode diagnosis penyakit petugas koder. Untuk meningkatkan ketrampilan petugas koder perlu sering diikut sertakan dalam pelatihan-pelatihan kodefikasi diagnosis penyakit yang diselenggarakan oleh pihak luar Puskesmas atau yang dikoordinir oleh Dinas Kesehatan.

Keakuratan kode diagnosis penyakit yang masih rendah sangat dipengaruhi oleh faktor-faktor: pengetahuan koder tentang kode diagnosis penyakit, pengalaman kerja dalam bidang kodefikasi diagnosis penyakit serta ketersediaan SOP kodefikasi diagnosis penyakit dan yang paling berpengaruh diantara ketiganya adalah pengetahuan koder tentang kode diagnosis penyakit yang mengacu pada standar klasifikasi kodefikasi diagnosis ICD-10. Peningkatan pengetahuan dan ketrampilan tenaga koder di Puskesmas sangat diperlukan, khususnya dalam penggunaan buku ICD-10 sebagai pedoman dalam melakukan pengkodean di Puskesmas untuk meningkatkan keakuratan dalam melakukan kode diagnosis penyakit. Diharapkan kedepannya Puskesmas sudah mempunyai tenaga profesional perekam medis tetap yang sesuai dengan kompetensi keilmuannya akan bertanggung jawab dalam pengkodean diagnosis penyakit di Puskesmas. Dokter, dokter gigi dan perawat adalah tenaga-tenaga medis dan para medis yang bertanggung jawab terhadap pelayanan perawatan dan pengobatan pasien, sehingga tidak dibebani lagi dengan tugas yang seharusnya menjadi tanggung jawab seorang profesi perekam medis. Penelitian lebih luas perlu dilakukan untuk memperkuat bukti faktor yang berperan dalam akurasi kode diagnosis oleh koder.

Manajemen Informasi Kesehatan Indonesia. 2015; 3(1), 59-64.

3. Suriawan NLES, Kartiko BH, dan Adhiwirawan B. Factors Affecting the Innaccuracy of Outpatient Disease Diagnosis Coding in General Surgery and Neurosurgery Polyclinics, Hospital X, Badung Regency. Jurnal Medicoeticolegal dan Manajemen Rumah Sakit. 2017; 6(3): 232-238.

4. Pramono AE dan Nuryati. Keakuratan Kode Diagnosis 
Penyakit Berdasarkan ICD-10 di Puskesmas Gondokusuman II Kota Yogyakarta. Jurnal Manajemen Informasi Kesehatan Indonesia. 2013; 1(1): 42-61.

5. Lestari AD. Analisis Tingkat Pengetahuan Petugas Rekam Paramedis dan Non Paramedis Tentang Pengkodean Penyakit di Puskesmas Mijen Kota Semarang. [Tugas Akhir]. Universitas Dian Nuswantoro, Semarang. 2014.

6. Sudra RI dan Pujihastuti A. Pengaruh Penulisan Diagnosis dan Pengetahuan Petugas Rekam Medis tentang Terminologi Medis terhadap Keakuratan Kode Diagnosis. Jurnal Manajemen Informasi Kesehatan Indonesia. 2016; 4(1): 67-72.

7. Maryati W, Murti B, and Indarto D. Factors Affecting the Quality of Diagnosis Coding and Medical Record at Dr. Moewardi Hospital, Surakarta. Journal of Health Policy and Management. 2016; 1(2): 61-70.

8. Yuniati DI. Analisis Hasil Koding yang Dihasilkan oleh Koder di Rumah Sakit Pemerintah X di Kota Semarang Tahun 2012. Jurnal Ekonomi Kesehatan Indonesia. 2012; 1(4): 167-174.

9. Farzandipour M, Sheikhtaheri A, and Sadoughi F. Effective Factors on Accuracy of Principal Diagnosis Coding Based on International Classification of Diseases, The 10 Revision (ICD10). International Journal of Information Management. 2010; 30(1): 7884.

10. Noor VMM, Ansyori A, dan Hariyanto T. Peran Pengetahuan dan Sikap Dokter dalam Ketepatan Kodefikasi diagnosis penyakit Diagnosis Berdasar ICD10. Jurnal Kedokteran Brawijaya. 2014; 28(1): 65-67.
11. Widjaya L dan Rumana NA. Faktor-faktor yang Mempengaruhi Keakurasian Koding Ibu Melahirkan dan Bayi di Beberapa Rumah Sakit Tahun 2014. [Skripsi]. Universitas Esa Unggul, Jakarta. 2014.

12. Santos S, Murphy G, Baxter K, and Robinson KM. Organisational Factors Affecting the Quality of Hospital Clinical Coding. Health Information Management. 2008; 37(1): 25-37.

13. Wibawa IMK, Bagia IW, dan Yulianthini NN. Analisis Kegagalan Pelatihan dalam Meningkatkan Produktivitas Kerja Karyawan. e-Journal Bisma Universitas Pendidikan Ganesha Jurusan Manajemen. 2016; 4(1): 1-13.

14. Rahayu H, Ernawati D, dan Kresnowati L. Akurasi Kode Diagnosis Utama pada RM 1 Dokumen Rekam Medis Ruang Karmel dan Karakteristik Petugas Koding Rawat Inap Rumah Sakit Mardi Rahayu Kudus Periode Desember 2009. Jurnal Visikes. 2011; 10(1): 1-5.

15. Windari A dan Kristijono A. Analisis Ketepatan Koding yang Dihasilkan Koder di RSUD Ungaran. Jurnal Riset Kesehatan. 2016; 5(1): 35-39.

16. Maimun N, Natassa J, Trisna WV, dan Supriatin Y. Pengaruh Kompetensi Koder Terhadap Keakuratan Dan Ketepatan Pengkodean Menggunakan ICD-10 di Rumah Sakit " $X$ " Pekanbaru Tahun 2016. Jurnal KesMARS. 2018; 1(1): 31-43.

17. Joosse $P$, de Jongh $M A$, van Delft-Schreurs $C C$, Verhofstad $\mathrm{MH}$, and Goslings JC. Improving Performance and Agreement in Injury Coding Using the Abbreviated Injury Scale: A Training Course Helps. Health Information Management Journal. 2014; 43(2): 17-22. 